Join, or Die - Philosophical Foundations of Federalism 



\section{Join, or Die - Philosophical Foundations of Federalism}

Edited by

Dietmar H. Heidemann and Katja Stoppenbrink 
ISBN 978-3-11-042658-8

e-ISBN (PDF) 978-3-11-042210-8

e-ISBN (EPUB) 978-3-11-042212-2

\section{Library of Congress Cataloging-in-Publication Data}

A CIP catalog record for this book has been applied for at the Library of Congress.

\section{Bibliographic information published by the Deutsche Nationalbibliothek}

The Deutsche Nationalbibliothek lists this publication in the Deutsche Nationalbibliografie; detailed bibliographic data are available on the Internet at http://dnb.dnb.de.

(c) 2016 Walter de Gruyter GmbH, Berlin/Boston

Cover image: “Join, or Die” (attributed to Benjamin Franklin); Public Domain

Printing and binding: Hubert \& Co. GmbH \& Co. KG, Göttingen

(2) Printed on acid-free paper

Printed in Germany

www.degruyter.com 